кuLTura - мeDia- теоцоgia

ISSN 2081-8971

$2017 \mathrm{nr} 29$, s. 158-171.

\title{
Obawy i nadzieje zwiazzane z technologia \\ interfejsów mózg-komputer - analiza jakościowa prac uczestników 2 etapu IV Olimpiady Medialnej - elementy składowe i preferencje odbiorców
}

Fears and hopes for the technology brain-computer interfaces - qualitative analysis of the work of the participants 2 Stage IV Media Olympiad.

\section{STRESZCZENIE:}

ABY UZYSKAĆ ODPOWIEDŹ NA PYTANIE: JAK MŁODZIEŻ PONADGIMNAZJALNA POSTRZEGA PROBLEMY ZWIĄZANE

Z NOWYMI TECHNOLOGIAMI INTERFEJSÓW MÓZGKOMPUTER, PRZEPROWADZONO BADANIE PRAC UCZESTNIKÓW 2. ETAPU IV OLIMPIADY MEDIALNEJ,

W KTÓRYM UCZESTNICY UDZIELILI ODPOWIEDZI NA PYTANIE DOTYCZĄCE ICH STOSUNKU DO TECHNOLOGII INTERFEJSÓW MÓZG-KOMPUTER. WYNIKI BADANIA SĄ PRÓBĄ OKREŚLENIA STOSUNKU MŁODYCH LUDZI ZAINTERESOWANYCH TEMATYKĄ MEDIALNĄ DO POSTĘPU TECHNICZNEGO I PROBLEMÓW ZWIĄZANYCH Z STOSUNKIEM CZŁOWIEKA DO ROZWIJAJĄCEJ SIĘ TECHNOLOGII.

\section{SŁOWA KLUCZOWE:}

MEDIA, UCZEŃ, INTERFEJS, SZKOŁA, KONKURS, INTERFEJS MÓZG-KOMPUTER

\section{ABSTRACT:}

TO GET THE ANSWER TO THE QUESTION OF HOW YOUNG PEOPLE PERCEIVE UPPER SECONDARY PROBLEMS ASSOCIATED WITH NEW TECHNOLOGIES OF BRAINCOMPUTER INTERFACES, WE SURVEYED THE WORK OF PARTICIPANTS 2ND STAGE IV MEDIA OLYMPIAD, IN WHICH PARTICIPANTS RESPONDED GOING TO CREATE ON THEIR RELATIONSHIP TO THE TECHNOLOGY OF BRAIN-COMPUTER INTERFACES. THE SURVEY RESULTS ARE AN ATTEMPT TO DETERMINE THE RATIO OF YOUNG PEOPLE TO TECHNICAL PROGRESS AND ISSUES ASSOCIATED WITH THE PLACE OF MAN IN A WORLD OF EVOLVING TECHNOLOGY.

\section{KEYWORDS:}

MEDIA, STUDENT, INTERFACE, SCHOOL, COMPETITION, BCI, BRAIN-COMPUTER INTERFACES 
W niniejszym artykule została podjęta próba odpowiedzi na pytanie, jaki stosunek do rozwoju technologii interfejsów mózg-komputer mają polscy nastolatkowie - uczestnicy IV edycji Olimpiady Medialnej w $2015 \mathrm{r}$. W jednym z pytań konkursowych etapu II poproszono ich o przedstawienie swojej opinii na temat: etyczne aspekty tworzenia interfejsów mózg-komputer. Zebrany materiał skategoryzowano metodą jakościowej analizy tekstu. Uczniowie wyrażają swoje opinie na temat oczekiwań i nadziei związanych z rozwojem tego typu technologii. Stanowi to pewną nowość w świetle dotychczasowej literatury przedmiotu dotyczącej tworzenia interfejsów mózg-komputer. Próbę podsumowania wyników analizy jakościowej przedstawiono w ostatniej części.

\section{Problem interfejsów mózg-komputer w literaturze przedmiotu}

We współczesnej literaturze przedmiotu najbardziej zaakcentowana jest interakcja pomiędzy uczestnikami procesu komunikacji - odbiorcą i nadawcą. Mowa tutaj o obustronnym oddziaływaniu i sprzężeniu zwrotnym, charakterystycznym dla komunikacji interpersonalnej i nowych mediów. Ogólnie przyjęte założenia odbioru i nadawania przekazu medialnego odnoszą się do schematu komunikacji zaproponowanego przez R. Osiepowicza Jakobsona ${ }^{1}$, który uzupełnił klasyczną wersję procesu komunikacji społecznej K. L. Bühlera ${ }^{2}$. Uwzględnia on sześć elementów składających się na proces komunikowania: nadawcę, odbiorcę, komunikat, kontekst, kod i kontakt.

W literaturze można jednak natrafić na pytania o możliwość komunikacji w przypadku, kiedy osoba pełniąca rolę nadawcy komunikatu nie jest w stanie samodzielnie go nadać. Przyczyną tego może być niepełnosprawność, choroba, terapia (lub jej skutki uboczne), zwiększone zmęczenie lub wahania stanu zdrowia. Dopuszcza się, że bariery te mogą się kumulować. W takich przypadkach, które w ostateczności nie pozwalają na samodzielną komunikację, źródłem nadania może stać się bezpośrednio mózg pacjenta z pominięciem jego aktywności fizycznej ${ }^{4}$. Ma to miejsce dzięki interfejsowi mózg-komputer (Brain-Computer Interface), który interpretując sygnał elektryczny odebrany z mózgu nadawcy przetwarza go do urządzenia zewnętrznego umożliwiającego nadanie komunikatu (np. syntezator głosu, komputer, tablet).

Interfejsy mózg-komputer wykorzystują pomiary aktywności elektrofizjologicznej do pozamięśniowej komunikacji człowieka z otoczeniem. W ten sposób ośrodkowy układ nerwowy człowieka jest w stanie łączyć się z komputerem, który odbiera sygnał EEG z kory mózgowej ${ }^{5}$. Połączenie z mózgiem człowieka odbywa się w sposób inwazyj-

Por. R. Jakobson, W poszukiwaniu istoty języka. Wybór pism, (red.) M. R. Mayenowa, t. 1, Warszawa 1989.

2 Zob. K. Bühler, Teoria języka, Kraków 2004.

3 Por. E. Mikołajewska, D. Mikołajewski, Interfejsy mózg-komputer jako rozwiązanie dla osób niepełnosprawnych z uszkodzeniami układu nerwowego, „Niepełnosprawność - zagrożenia, problemy, rozwiązania” $2012 \mathrm{nr} 3$ z. 4, s. 25-26.

4 Por. A. Cudo, E. Zabielska, B. Bałaj, Wprowadzenie w zagadnienie interfejsów mózg-komputer, „Studia z Psychologii w KUL” 2011, nr 17, s. 189.

5 Por. E. Mikołajewska, D. Mikołajewski, Interfejsy... dz. cyt., s. 25-26. 


\section{OBLICZA MEDIÓW I KOMUNIKACJI}

ny lub nieinwazyjny (w zależności od wykorzystanej technologii) ${ }^{6}$. Niezależnie od metody, celem BCI jest zwiększenie jakości życia codziennego, umożliwienie badań i terapii, zwiększenie samodzielności pacjentów oraz ich motywacja. Komunikacja za pośrednictwem BCI może zachodzić nawet w przypadkach poważnych zaburzeń świadomości. Badania wykazują, że „u pacjentów w stanie minimalnej świadomości pozwalają przypuszczać, że zapewnienie bezpośredniego wyjścia z ośrodkowego układu nerwowego pacjenta (...) może umożliwić mu zarówno komunikację pozamięśniową, jak i, na skutek realizacji prostych zadań wymagających orientacji przestrzennej oraz planowania ruchu, przyczynić się do odzyskania poszczególnych funkcji i, w rezultacie, poprawy stanu zdrowia ${ }^{7}$."

Interfejsy mózg-komputer są nieustannie udoskonalane, ponieważ trudnym jest dostosowanie urządzenia do ludzkiego mózgu charakteryzującego się pewną zmiennością. W niektórych przypadkach sygnały mogą być źle interpretowane, albo urządzenie potrzebuje kilkunastu prób, aby poprawnie odczytać informację ${ }^{8}$. Trudność w interpretacji przez maszynę sygnałów płynących od człowieka może być także spowodowana czynnikiem ludzkim, jak np. rozproszenie uwagi lub uruchomieniem procesów opartych na wyobraźni ${ }^{9}$. Brak elastyczności interpretacyjnej dodatkowo utrudnia stosowanie BCI na szeroką skalę, ponieważ poza warunkami laboratoryjnymi człowiek jest poddany większej liczbie czynników rozpraszających, jak np. sygnały dźwiękowe, dekoncentracja podczas poruszania się $\mathrm{w}$ tłumie $\mathrm{i}$ inne.

Aby tego typu interfejs mógł być szeroko wykorzystywany przez człowieka w życiu codziennym powinien spełniać następujące warunki:

a) Jego aplikacja powinna być bezinwazyjna, charakteryzować się stabilnością podczas użytkowania oraz kłaść nacisk na szybkość transferu informacji ${ }^{10}$,

b) Użytkowanie go musi cechować się bezpieczeństwem oraz brakiem skutków ubocznych ${ }^{11}$,

c) Produkcja powinna mieć charakter masowy z możliwością indywidualnego dostosowania do potrzeb i możliwości kupującego ${ }^{12}$,

d) Uwzględniona powinna zostać elastyczność względem zmienności czynnika ludzkiego, który w zależności od dnia może być w różnym stopniu kompatybilny z urządzeniem ${ }^{13}$.

\footnotetext{
Por. Por. A. Cudo, E. Zabielska, B. Bałaj, Wprowadzenie w zagadnienie... dz. cyt., s. 199.

E. Michałowska, D. Mikołajewski, Interfejsy ... dz. cyt., s. 29.

Por. A. Cudo, E. Zabielska, D. Zapała, Interfejsy mózg-komputer oparte... dz. cyt., s. 203.

9 Por. S. Paszkiel, A. Błachowicz, Zastosowanie BCI do sterowania robotem mobilnym, w: „Pomiary Automatyka Robotyka” 2012, nr 2, s. 270. Zob. H. Cecotti, Spelling with non-invasive Brain-Computer Interfaces - Current and future trends, Journal of Physiology, Paryż 2011, t. 105, s. 106-114.

11 Por. E. Mikołajewska, D. Mikołajewski, Interfejsy..., dz. cyt., s.23-24.

12 Por. Tamże.

13 Por. N. Birbaumer, Breaking the silence: Brain-computer interfaces (BCI) for communication and motor control, Psychophysiology 2006 t. 43, s. 518.
}

10 
Zastosowanie BCI może także mieć wpływ na mobilność osób chorych lub niepełnosprawnych. Mowa o takich schorzeniach jak stwardnienie zanikowe boczne, udar mózgu i uraz rdzenia kręgowego ${ }^{14}$. Przeprowadzono badania nad wózkiem dla osób niepełnosprawnych sterowanym przez sygnały płynące z mózgu ${ }^{15}$. Konkurencją dla tego typu pojazdów są egzoszkielety sterowane na tej samej zasadzie. Zdanie to potwierdza N. Birbaumer, który z optymizmem odnosi się do rozwoju możliwości sterowania protezami za pomocą BCI przez osoby sparaliżowane ${ }^{16}$.

Możliwy jest także rozwój BCI w koegzystencji z rozszerzoną rzeczywistości - AR (Augmented Reality) ${ }^{17}$. Dotychczasowo urządzenie korzystające z AR, jak Google Glass, stawały się przedłużeniem zmysłów ${ }^{18}$ odbiorcy technologii nanosząc na istniejący świat wirtualne elementy oraz ułatwienia. Rozwój technologii oferuje możliwość obsługi urządzeń AR jedynie za pomocą bezinwazyjnych form BCI z pominięciem fizycznej interakcji człowieka, jak np. ruch, naciśnięcie przycisku lub skupienie spojrzenia w danym punkcie. Jako przykład połączenie BCI z AR można przytoczyć grę „Brain-pong”" ${ }^{19}$, gracze za pomocą przetworzonego sygnału EEG przenoszą wirtualną piłeczkę. Obecnie sterowanie oparte na potencjale myślowym wykorzystywane jest także w bardziej zaawansowanych grach takich, jak „Alpha-World of Warcraft BCI”20. Technologia rozszerzonej rzeczywistości może dodatkowo wykorzystywać wyświetlacze 3D. Rodzi do jednak niebezpieczeństwo narażenia użytkownika takiego interfejsu na korzystanie z niego dłużej, niż jest to konieczne do komunikowania. W tych przypadkach potencjalne zagrożenie wynika z braku długofalowych badań dotyczących zmian wywołanych takim użytkowaniem, także u dzieci ${ }^{21}$.

Główne zagadnienia podejmowane w badaniach nad interfejsami mózg-komputer dotyczą samej technologii oraz możliwości jej wykorzystania w obszarze zdrowia i rozrywki. Istotnym brakiem są jednak prace dotyczące stosunku audytoriów - użytkowników mediów do rozwiązań w tym zakresie. Powodem tego braku może być niedostateczny jeszcze stopień upowszechnienia tych technologii w społeczeństwie, a także mity dostarczane przez literaturę i filmy science fiction. Stawianie młodym lu-

14 Por. J. R. Wolpaw, N. Birbaumer, D. J. McFarland, G. Pfurtscheller, T. M. Vaughan, Brain-computer interfaces for communication and control, Clinical Neurophysiology 2002 t. 113, s. 767.

ewski, Interfejsy..., dz. cyt. s. 30.

Por. N. Birbaumer, dz. cyt., s. 520.

Zob. Y. Renard, F. Lotte, G. Gibert, M. Congedo, M. Maby, V. Delannoy, O. Bertrand, A. Lécuyer, OpenViBE: An Open-Source Software Platform to Design, Test, and Use Brain-Computer Interfaces in Real and Virtual Environments, Presence 2010 t. 19, z. 1, s. 35-53.

18 Zob. McLuhan M., Zrozumieć media: przedłużenia człowieka, Warszawa 2004.

19 Zob. M. M. Jacobson, M. Mappus, Applications for Brain-Computer Interfaces, w: Brain-Computer Interfaces: Applying our Minds to Human-Computer Interaction part 2, s. 89-103.

20 A. Ceglińska, M. Olszewski, Nieinwazyjny interfejs mózg-komputer do zastosowań technicznych, „Pomiary Automatyka Robotyka” 2015, nr 3, r. 19, s. 10.

21 E. Mikołajewska E., D. Mikołajewski, The movement of a human being in the medical exoskeleton - the anthropomorfic aspects, “Antropomotoryka” 2012, nr 57, s. 115-121. 
dziom pytań o planowanie i upowszechnienie nowych technologii, wydaje się być istotną praktyką prowadzącą do pogłębienia ich świadomości technologicznej i rozwijania nowych kompetencji medialnych.

\section{Metodologia}

Badania zostały przeprowadzone na podstawie analizy jakościowej prac uczestników 2 etapu IV Olimpiady Medialnej. W ramach tego etapu musieli oni odpowiedzieć na 25 pytań zamkniętych jednokrotnego wyboru oraz 5 otwartych - każde z limitem 1500 znaków ze spacjami ${ }^{22}$. Przedmiotem badania było jedno z pytań otwartych brzmiące: „Przedstaw etyczne problemy związane ztworzeniem interfejsów mózg-komputer”. Etap przebiegał w pięciu placówkach Uniwersytetu Humanistyczno-Społecznego SWPS w: Sopocie, Katowicach, Wrocławiu, Poznaniu i Warszawie, a także w 1 Liceum Ogólnokształcącym w Rzeszowie. Nad przebiegiem konkursu czuwali delegaci komitetu głównego Olimpiady Medialnej odpowiedzialni za dyscyplinę czasową oraz samodzielną pracę uczestników.

Do pierwszego etapu przystąpiło 253 uczestników, do kolejnego dostało się 114 z nich, ale 12 nie zgłosiło się w wyznaczonym miejscu i czasie, aby przystąpić do testów. W badaniu przeanalizowano 102 prace. Podczas poniższego opracowania wyników trzeba zaznaczyć, że 7 prac było niezgodnych z tematem. Uczestnicy wpisywali odpowiedź na inne pytanie konkursowe (jedno z pozostałych czterech) lub w ogóle nie udzielali odpowiedzi. Nie były one brane pod uwagę $w$ dalszej części opracowania.

Analizy prac uczestników Olimpiady Medialnej były również prowadzone w poprzednich latach. Do tej pory została m.in. podjęta próba weryfikacji odpowiedzi na pytanie o plan ramowy TVP1 z II edycji Olimpiady Medialnej przez dr. hab. Piotra Drzewieckiego w 2013 roku $^{23}$. Opublikowano także analizę stosunku uczestników do repozytoriów cyfrowych (pytanie z III Olimpiady Medialnej) ${ }^{24}$. Niniejszy artykuł stara się odpowiedzieć na nieporuszone dotychczas pytanie dotyczące stosunku młodych ludzi do rozwoju technologii mediów na przykładzie tworzenia interfejsów mózg-komputer.

\section{Analiza jakościowa wypowiedzi uczestników Olimpiady Medialnej}

Analiza jakościowa wypowiedzi uczestników IV Olimpiady Medialnej pozwoliła na wyodrębnienie trzech głównych kategorii zawierających w sobie ich spostrzeżenia i odniesienia dotyczące interfejsów mózg-komputer. W omówieniu każdej kategorii podano przykładowe wypowiedzi uczestników oraz komentarz analityczny, zgodnie z sugestia-

\footnotetext{
Zob. Fundacja Nowe Media, Regulamin IVOlimpiady Medialnej, Warszawa 2014, archiwum autora.

Zob. P. Drzewiecki, Młodzi o programie ramowym TVP1. Analiza jakościowa prac finalistów II edycji Olimpiady Medialnej w 2013 r., w: Olimpiada Medialna, Badania nad świadomością uczestników, Warszawa 2014, s. 39-52. uczestników, Warszawa 2014, s. 53-65.
} 
mi Rogera D. Wimmera i Josepha R. Dominicka, dotyczącymi opracowywania badań jakościowych i proponowanego układu przykład-komentarz ${ }^{25}$.

\section{Ułatwienia w życiu codziennym}

Uczestnicy IV Olimpiady Medialnej widzą szansę w używaniu interfejsu mózg-komputer. Zwracają uwagę na możliwości płynące z ułatwień życia codziennego. Jako „ułatwienia” rozumiane jest tutaj wsparcie dla osób niepełnosprawnych, zwiększenie dostępu do informacji oraz poprawienie komfortu życia. Włączono do tej grupy również rozwój technik medycznych. Pośród wszystkich prac uczestników, przykłady możliwości rozwoju oraz polepszenia jakości życia dostrzega się w 17 przykładach.

„Korzystanie z interfejsów mózg-komputer jest uzasadnione tylko i wylącznie w tym przypadku kiedy ktoś jest niepełnosprawny i w ten sposób ta technologia ułatwi mu poprawne funkcjonowanie w społeczeństwie”26.

Pozytywnym aspektem wypowiedzi wydaje się zauważenie potrzeby osób z niepełnosprawnością oraz szukanie sposobów na polepszenie jakości ich życia oraz funkcjonowania w środowisku. Jednak za nieuzasadnione można uznać ograniczenie możliwości korzystania z tej technologii tylko do ich grona. Należałoby wziąć pod uwagę możliwości płynące z technologii oraz ich wpływ na życie każdego użytkownika oraz wykonywanej przez niego pracy. Szersze zastosowanie BCI przyczyniłoby się do jego popularyzacji na rynku komercyjnym, gdzie konkurencja pomiędzy producentami byłaby gwarantem dążenia do rozwoju technologii i jej uniwersalności.

„Ułatwia on obsługę urządzeń elektronicznych, ponieważ tak naprawdę ogranicza ją do myśli.,"27

Dzięki interfejsowi mózg-komputer nie tylko można użytkować pojedyncze urządzenia elektryczne, dostosowane do tego rodzaju interfejsu ${ }^{28}$, ale również zarządzać większą ich liczbą. Przejawem tego mogą być próby stworzenia „inteligentnego domu”, w którym poprzez BCI można włączać/wyłączać światła, kontrolować okna, telewizor i inne sprzęty domowe ${ }^{29}$. Daje to możliwość samodzielnego funkcjonowania w środowisku domowym nie tylko osób z niepełnosprawnością, ale także osób starszych pozbawionych dawnej sprawności fizycznej.

R. D. Wimmer, J. R. Dominick, Mass media. Metody badań, Kraków 2008, s. 202.

Wypowiedź użytkownika 1223.

Por. Fragment wypowiedzi uczestnika 1215.

Zob. D. J Cook., W. Song, Ambient Intelligence and Wearable Computing: sensors on the body, in the home, and beyond, "Journal of Ambient Intelligence and Smart Environments" $2009 \mathrm{nr}$ 1(2), s. 83-86.

Por. C. Guger, Using a brain/computer interface for smart-home control, "PerAda Magazine Toward pervasive adaptation”, 2009, s. 1-2; Zob. A. Broniec, J. Chodak, Sterowanie prostym urządzeniem elektrycznym za pomocą sygnału EEG, „Automatyka”, Akademia Górniczo-Hutnicza im. Stanisława Staszica w Krakowie, 2009, nr 13, s. 1059-1067. 


\section{OBLICZA MEDIÓW I KOMUNIKACJI}

„Ochrona życia ludzkiego” pojmowana była jako: „rozwiązanie mogło by zostać wykorzystane w celu stworzenia zaawansowanego robota bojowego, który mógłby wykonywać operacje zamiast za żołnierzy, co przyczyniłoby się do mniejszej ilości ofiar na wojnie" ${ }^{30}$.

Podjęto już próby skonstruowania robota, którym steruje się za pomocą sygnału $\mathrm{EEG}^{31}$. Założeniem autorów było stworzenie maszyny, która ułatwiałaby funkcjonowanie w środowisku domowym osobom starszym oraz z niepełnosprawnością. Jego wsparcie polega na przykład na możliwości przenoszenia przedmiotów. Autorzy zauważają problem starzenia się społeczeństwa, które będzie potrzebowało pomocy w życiu codziennym, a tę mogą przejąć w znaczniej części na siebie urządzenia i maszyny, także sterowane za pomocą sygnałów EEG ${ }^{32}$.

Zaproponowane przez uczestnika Olimpiady Medialnej rozwiązanie, dotyczące technologii militarnej, może znaleźć zastosowanie w oddziałach saperskich. Obecnie wykorzystuje się w nich roboty zdalnie sterowane, ale na chwilę obecną zastosowanie w nich BCI wydaje się niepraktyczne ze względu na duże znacznie artefaktów podczas odbierania sygnału od użytkownika. Trwają obecnie badania nad dostosowaniem tego typu interfejsów do codziennego użytku, na przykład na zatłoczonej ulicy, jednak wykorzystanie go w warunkach podwyższonego stresu i rozproszenia uwagi na polu działań wojskowych wydaje się nieosiągalne.

„Interfejs mózg-komputer jest w zasadzie dobrym sposobem na rozwiązanie problemów np. medycznych, gdzie zaawansowane maszyny mogłyby pomagać chorym lub po prostu być dźwignią wspomagającą rozwój urządzeń domowych.,"33

Jako szansę dla chorych można rozumieć nie tylko systemy wykorzystywane $\mathrm{w}$ medycynie, ale także $\mathrm{w}$ rehabilitacji pacjenta. Zalicza się do nich stosowanie egzoszkieletów (stymulujących rozwój samodzielnego poruszania się) ${ }^{34}$, i neuroprotez (które nie muszą się odnosić jedynie do układu ruchu, ale także do narządów wzroku i słuchu $)^{35}$, które po przeszkoleniu pacjenta i jego opiekunów mogą być stosowane także w środowisku domowym.

\section{Zjawiska negatywne}

Uczestnicy IV Olimpiady Medialnej wyszczególniali również negatywne zjawiska, jakie mogą mieć miejsce przy zastosowaniu BCI. Uczestnicy wymieniają 152 przykłady nega-

\footnotetext{
$30 \quad$ Fragment wypowiedzi uczestnika 1174.

Por. S. Paszkiel, A. Błachowicz, Zastosowanie BCI..., dz. cyt., s. 270-274.

Tamże.

33 Fragment wypowiedzi uczestnika 1122.

34 Por. E. Mikołajewska, D. Mikołajewski, Interfejsy..., dz. cyt. s. 30.

35

Por. Tamże, s. 23.
} 
tywnych następstw użytkowania i wprowadzenia do powszechnego obiegu interfejsu mózg-komputer.

Można zauważyć tendencję do obawy o podstawowe prawa człowieka, czyli prawo do wolności i prywatności, nie tylko ze względu na zagrożenie ze strony innych osób, ale także samych maszyn. Stawiane są także pytania o aspekty zdrowotne oraz o sposób, w jaki BCIs będą podłączane do użytkownika. Młodzi ludzie zwracają uwagę także na fizyczne oraz psychiczne aspekty zdrowotne wynikające z użytkowania takiego interfejsu, jak również widzą zagrożenie wynikające z uzależnienia się od technologii. Oddzielnym zagadnieniem jest pogłębienie problemu izolacji człowieka w społeczeństwie. Ściślejsze powiązanie jego życia ze światem technologii zdaje się mieć negatywny wpływ na jego relacje międzyludzkie.

„(...) według etyki lekarze bądź naukowcy nie powinni przeprowadzać doświadczeń na mózgu, ponieważ mogłoby to doprowadzić do wpływania na myśli ludzi. Rożnego rodzaju przestępcy bądź tajne wydziały mogłyby w ten sposób torturować oraz manipulować ludźmi w celu uzyskania informacji. Byłoby to wtedy sprzeczne z prawem człowieka do wolności.”36

Obawy dotyczące etycznego przeprowadzania eksperymentów na ludziach nie tyczą się jedynie zagadnień medycznych związanych z interfejsami mózg-komputer. Wszelkie badania i eksperymenty powinny być przeprowadzane z poszanowaniem norm etycznych, molarnych i prawnych. Tak samo, jak w innych dziedzinach życia, człowiek musi mieć zagwarantowane podstawowe prawa do wolności i prywatności. O ile zasadnym wydaje się podkreślanie potrzeby popularyzacji dobrych praktyk w badaniach naukowych lub medycznych, postulaty dotyczące możliwości kradzieży informacji z mózgu za pośrednictwem BCI wydają się mocno przesadzone, zwłaszcza, że interfejsy mózg-komputer to urządzenia jednokierunkowe, jedynie zbierające informacje wysyłane przez użytkownika. Dużo więcej informacji o użytkowniku internetu można uzyskać dzięki portalom społecznościowym ${ }^{37}$.

Analizując prace uczestników można było zauważyć nacisk kładziony na aspekt wolności osobistej i wyboru ${ }^{38}$ oraz prawa do prywatności. Może on wynikać zarówno z przyczyn ciągłego dostępu do danych osobowych lub zainteresowań na podstawie informacji udostępnianych o sobie, na przykład na portalach społecznościowych (gdzie dane te są publikowane na zasadzie dobrowolności) lub charakterystycznej dla młodzieży potrzeby podkreślania swoich praw i niekiedy nadmiernego ich akcentowania, co można określić postawą roszczeniową, charakterystyczną dla pokolenia $\mathrm{Y}^{39}$.

$36 \quad$ Fragment wypowiedzi użytkownika 998.

37 Zob. M. Kosinski, D. Stillwell, T. Graepel, Private traits and attributes are predictable from digital records of human behavior, "Proceedings of the National Academy of Sciences" 2013, nr 110.15, s. 58025805.

38 Por. D. Tapscott, Cyfrowa dorosłość: Jak pokolenie sieci zmienia nasz świat, Warszawa 2010, s. 141-146.

39

Por. Tamże, s. 263-266. 


\section{OBLICZA MEDIÓW I KOMUNIKACJI}

„Nie oszukujmy się badania nad interfejsami komputer-mózg wywołują w ludziach strach przed końcem ich dominacji. Coś co ma teoretycznie człowiekowi pomóc rozwiązać problemy neurologiczne, ułatwić codzienne życie wywołuje strach przed zdominowaniem człowieka przez maszyny." ${ }^{40}$

Wizja dominacji maszyny nad człowiekiem może wynikać z dzieł kultury popularnej, w której ten motyw jest często wykorzystywany ${ }^{41}$. Przedstawia technologię jako maszynę rozumującą jedynie w oparciu o zasady matematyki, wg których ludzie są zagrożeniem sami dla siebie lub gatunku maszyn, co sprawia, że muszą zostać wyeliminowani. Oczywiście w dziełach kultury popularnej motyw relacji człowieka z technologią jest znacznie bogatszy i wielowymiarowy, co również przedstawiają inne produkcje filmowe ${ }^{42}$, jednak wśród wypowiedzi uczestników Olimpiady Medialnej przytaczane były przykłady na podobieństwo powyższego.

„Kolejnym problemem mogą być zjawiska niepożądane, tj. śmierć pacjenta z powodu błędu urządzenia - jak wszyscy wiemy, wszystkie urządzenia mają wady i kiedyś się psują, jedna wada w urządzeniu mogłaby decydować o śmierci bądź życiu pacjenta, rozwój hackerstwa na dalszą przestrzeń życiową, ingerencja maszyn w życie ludzi." ${ }^{43}$

Na podstawie tej wypowiedzi można wywnioskować, że użytkowanie technologii BCI niesie ze sobą niebezpieczeństwa związane z wadliwym działaniem urządzenia lub efektami ubocznymi stosowania go. Klasyfikując technologię BCI, można założyć, że inwazyjne metody pobierania sygnału EEG generują znacznie większe ryzyko uszczerbku na zdrowiu pacjenta. Kolejnym zagrożeniem jest brak badań nad skutkami długofalowego użytkowania interfejsów mózg-komputer. Od strony technicznej wymagane jest zapewnienie stałego serwisowania tych interfejsów oraz badań kontrolnych, które mogłyby również być wykorzystane do określenia wpływu urządzenia na człowieka.

„Jak bardzo świadomość posiadania maszyny ingerującej w działania człowieka zmieniła by psychikę jednostki ludzkiej?” ${ }^{44}$

Urządzenia sterowane za pomocą BCI działają w sposób jednokierunkowy. Odbierają sygnał EEG i przekazują go do urządzenia. Proces ten przebiega tylko w jednym kierunku. Jednak zasadnym jest pytanie o wpływ użytkowania takiego interfejsu, zwłaszcza obsługującego środowiska wirtualne lub rozszerzonej rzeczywistości, na psychikę

\footnotetext{
$40 \quad$ Fragment wypowiedzi użytkownika 1175.

Zob. J. Cameron (reż.), Terminator, USA, Wielka Brytania, 1984; L. Wachowski, L. Wachowski, Matrix, USA, Australia, 1999.

Zob. S. Spielberg (reż.), A.I.: Sztuczna Inteligencja, USA, 2001.

Fragment wypowiedzi użytkownika 1205.

Fragment wypowiedzi użytkownika 1221.
} 
użytkownika. BCI nie służy już jedynie do komunikowania się z ludźmi, ale także stwarza pole dla rozrywki, zwłaszcza w połączeniu z możliwościami rozszerzonej rzeczywistości oraz środowiska komputerowego.

„Także kontakty z ludźmi, które powinny być realne zastępuje się konferencjami internetowymi co buduję mur komunikacyjny między ludźmi." ${ }^{45}$

Powyższa wypowiedź może odnosić się do specyfiki komunikacji w społeczeństwie korzystającym z nowych mediów. Sam interfejs mózg-komputer, na obecnym etapie rozwoju technologii, nie wydaje się być optymalnym narzędziem do komunikacji międzyludzkiej. Jest natomiast szansą dla osób niemogących tego robić w inny, wymagający ingerencji fizycznej sposób.

\section{Aspekt ekonomiczny}

Młodzież biorąca udział w 2 etapie IV Olimpiady Medialnej poruszyła także aspekt ekonomiczny związany z zastosowaniem interfejsu mózg-komputer. Obawiano się zmniejszenia liczby miejsc pracy, zastąpienia człowieka przez maszyny, spadku kosztów produkcyjnych oraz możliwości nieustannej pracy generującej większe zyski.

„Komputery wyparly pracę ludzką i ciągle są udoskonalane, by mogły robić za nas więcej. Tylko problem rodzi się w tym miejscu - im maszyna inteligentniejsza tym droższa, a im więcej maszyn tym mniej pracowników, czyli mniejsze zarobki, większy odsetek bezrobotnych." ${ }^{46}$

Kwestia rynku pracy zdaje się być ważnym tematem w dobie ciągłego postępu technologicznego. Zauważalna jest tendencja zastępowania pracowników wyspecjalizowanymi maszynami. Za przykład mogą posłużyć te pracujące w firmie Amazon, gdzie odpowiadają za pakowanie przesyłek, a także (w ramach pilotażowego programu w Wielkiej Brytanii) za dostarczanie ich dronami do odbiorców ${ }^{47}$. Nie powinno być to znaczącą przeszkodą dla przedstawicieli pokolenia Y, ponieważ zmiana trybu pracy typowego dla poprzednich pokoleń zakłada nieprzywiązywanie się na stałe do jednego miejsca pracy oraz ciągłą potrzebę dostosowywania swoich kwalifikacji do potrzeb rynku pracy ${ }^{48}$. Obawy te mogą być przeniesieniem rozterek rodziców na dzieci, którzy jako przedstawiciele poprzedniego pokolenia wykazującego inne cechy, mogą nie odnajdywać się w nowych warunkach.

\footnotetext{
$45 \quad$ Fragment wypowiedzi użytkownika 1106.

46 Fragment wypowiedzi użytkownika 1125.

47 Por. S. Shead, Amazon wciąż automatyzuje magazyny. Ile robotów w nich pracuje?, http://businessinsider.com.pl/technologie/firmy/w-magazynach-amazona-pracuje-coraz-wiecej-robotow/h8knyw8 (dostęp: 23.10.2017 r.).

48 Por. W. Wrzesień, Czy pokoleniowość nam się nie przydarzy? Kilka uwago współczesnej polskiej młodzieży. „Nauka”, 2007, nr 3, s. 142.
} 
Jednak rozwój interfejsów mózg-komputer może być związany z robotyzacją zakładów pracy, przy obecnym stanie badań, jedynie jako jeden z efektów rozwoju technologicznego. Możliwe jednak, że ten rozwój przyczyni się do większej aktywizacji zawodowej osób z niepełnosprawnością, które za pomocą tych interfejsów będą mogły pracować nie tylko w branżach informatycznych, ale także jako operatorzy maszyn pracujących w firmach na równi z osobami pełnosprawnymi.

\section{Dyskusja nad wynikami analizy}

Przeprowadzone badanie wykazuje, że młodzi ludzie zauważają zarówno pozytywne, jak i negatywne potencjalne skutki zastosowania BCI. Ich wiedza zdaje się jednak być poglądowa, a wyobrażenia i przypuszczenia dotyczące interfejsów mózg-komputer wykraczają poza obszar rozwoju badań nad nimi. Część z uczestników bazuje na dziełach kultury popularnej, która w sposób prosty i jednowymiarowy prezentuje możliwość utraty kontroli przez człowieka nad skonstruowaną maszyną. Podkreślali możliwość ograniczenia wolności człowieka powodowaną złymi intencjami osób trzecich. Rodzi to pytanie o to, czy maszyna może być szkodliwa sama w sobie, czy przyczyną niebezpieczeństwa jest człowiek, który decyduje jak się nią posłużyć.

Uzasadnione zdają się być obawy dotyczące problemów zdrowotnych zarówno fizycznych, jak i psychicznych. Unikalność ludzkiego organizmu może być przyczyną odrzucenia lub niedostosowania się do ograniczonych ilościowo konfiguracji interfejsu. Mogłoby się również okazać, że nie każdy posiada predyspozycje psychiczne do zwiększenia swoich możliwości za pomocą takiego interfejsu, a także do samej zmiany percepcji.

Poruszone kwestie ekonomiczne, zarówno dotyczące rozwarstwienia społecznego ze względu na stan posiadania, jak również obawa o miejsce pracy, swoje lub rodziców, zdaje się mieć podłoże w szybkiej ewolucji form zatrudnienia w Polsce, niestabilności miejsca pracy i obaw z tym związanych, a także powstania nowej grupy społecznej nazywanej prekariatem ${ }^{49}$.

Istnieje wyraźne zapotrzebowanie na przedstawienie mediów jako wciąż rozwijającej się technologii, o której przyszłości należy dyskutować. Obecne „pokolenie Y”, wkraczające na rynek pracy powinno wykazywać większą nadzieję związaną z informatycznym obszarem zawodowym, który staje się obecny w coraz większej liczbie zawodów pierwotnie z nim niezwiązanych. Ponadto, istnieje potrzeba wskazania właściwego schematu podejmowania sądu nad zjawiskiem medialnym w oparciu o rzetelnie zebrane informacje oraz zestawienie ich ze sobą w oparciu o własny system wartości. Przyczyniłoby się to do wytworzenia schematu oceniania gruntownie zbadanego tematu w myśl edukacji medialnej.

Zdaje się być zasadnym wzmożenie przedstawiania pozytywnej roli technologii i mediów przy właściwym ich użytkowaniu przez człowieka. Jest to zadanie realizowane przez edukację medialną. Jej fundamenty teoretyczne zdają się nie pełnić dominującej roli w sposobie przedstawiania mediów społeczeństwu. Słusznie uwzględniane są w niej

Zob. D. Bell, Kulturowe sprzeczności kapitalizmu, Warszawa 1994. 


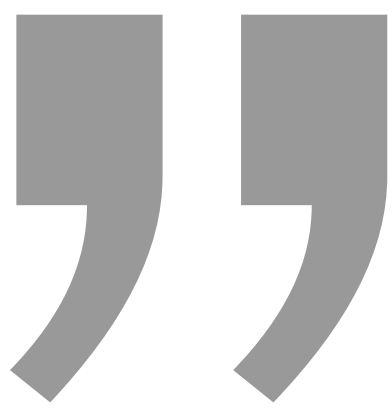

Istnieje wyraźne zapotrzebowanie na przedstawienie mediów jako wciąż rozwijającej się technologiil, o której przyszłości należy dyskutować. Obecne „pokolenie Y”, wkraczające na rynek pracy powinno wykazywać większą nadzieję związaną z informatycznym obszarem zawodowym, który staje się obecny w coraz większej liczbie zawodów pierwotnie z nim niezwiązanych.

niebezpieczeństwa wynikające z użytkowania mediów, jednak błędem jest przypisywanie im roli dominującej w procesie nauczania.

Zadanie to mogłoby zostać przejęte przez organizacje pozarządowe. Na chwilę obecną realizują one inicjatywy mające na celu edukację w kwestii świadomego korzystania z mediów (np. Fundacja Nowe Media), realizację programów promujących kształtowanie bezpiecznych postaw i zachowań w internecie (np. projekt „Cybernauci” - Fundacja Nowoczesna Polska), włączenie medialne i technologiczne osób starszych (np. Fundacja Zaczyn). Wymagałoby to jednak utworzenia planu koordynującego zadania współpracujących organizacji w celu wspólnego kompleksowego zaspokojenia zapotrzebowania na kształcenie w zakresie edukacji medialnej.

Pozytywną postawę wobec BCI może również kształtować pogłębienie zrozumienia przez młodzież problemów i potrzeb osób niepełnosprawnych lub z zaburzeniami świadomości. Przyczyną obecnej sytuacji zdaje się nie być jedynie niedobór wiedzy o potrzebach tych osób, którą można uzupełnić poprzez osobiste poznanie i integrację prowadzącą do postawy empatycznej opartej na zrozumieniu, a nie intuicyjnym współczuciu.

\section{Konkluzja}

Młodzież będąca uczestnikami II etapu IV Olimpiady Medialnej, pomimo braku specjalistycznej wiedzy, zdaje się właściwie interpretować główne wyzwania stojące przed interfejsami mózg-komputer. Między innymi zauważa potrzebę przeprowadzenia badań w zakresie długofalowego użytkowania interfejsów mózg-komputer, aby określić ewentualny wpływ na stan zdrowia użytkownika. Duża liczba negatywnych odniesień do technologii BCI wynika w głównej mierze z braku podstawowej wiedzy o obecnym stanie badań nad technologią oraz jest potęgowana dużym natężeniem fantastycznych wizji zawartych w dziełach kultury popularnej. Istnieje potrzeba uświadomienia młodym ludziom w jaki sposób powinni weryfikować swoje wątpliwości lub lęki powstałe na ich bazie. 


\section{OBLICZA MEDIÓW I KOMUNIKACJI}

Zauważalna jest także przewaga postawy charakteryzującej się obawą przed następstwami nowych technologii. Jest to wyzwanie dla edukacji medialnej, aby użytkownicy dostrzegali zarówno zagrożenia, jak i szanse z nimi związane. Zasadnym rozwiązaniem wydaje się kompleksowe przedstawienie problematyki, które uwzględni zagrożenia, ale także możliwości wynikające z właściwego użytkowania technologii. Dopiero na tej podstawie każda z osób podejmująca tę tematykę będzie mogła właściwie, zgodnie $\mathrm{z}$ aktualną wiedzą oraz własnym systemem wartości ocenić zjawisko. Nie chodzi o konkretne rozpatrzenie przykładu interfejsów mózg-komputer i zaprezentowanie tylko tej jednej technologii, ale na tym przykładzie zaproponowanie schematu, który można odnieść do każdej nowej.

\section{BIBLIOGRAFIA:}

Bell D., Kulturowe sprzeczności kapitalizmu, Warszawa 1994.

Birbaumer N., Breaking the silence: Brain-computer interfaces (BCI) for communication and motor control, "Psychophysiology" 2006 t. 43, s. 517-532.

Broniec A., Chodak J., Sterowanie prostym urządzeniem elektrycznym za pomocą sygnału EEG, „Automatyka”, Akademia Górniczo-Hutnicza im. Stanisława Staszica w Krakowie, 2009, nr 13, s. 1059-1067.

Bühler K., Teoria języka, Kraków 2004.

Cameron J. (reż.), Terminator, USA, Wielka Brytania, 1984;

Cecotti H., Spelling with non-invasive Brain-Computer Interfaces - Current and future trends, "Journal of Physiology”, Paryż 2011, t. 105, s. 106-114.

Ceglińska A., Olszewski M., Nieinwazyjny interfejs mózg-komputer do zastosowań technicznych, „Pomiary Automatyka Robotyka” 2015, nr 3, r. 19, S. 5-14.

Cook D. J., Song W., Ambient Intelligence and Wearable Computing: sensors on the body, in the home, and beyond, "Journal of Ambient Intelligence and Smart Environments” 2009, nr 1(2), s. 83-86.

Cudo A., Zabielska E., Bałaj B., Wprowadzenie w zagadnienie interfejsów mózg-komputer, „Studia z Psychologii w KUL” 2011, nr 17, s. 189-211.

Drzewiecki P., Korzystanie z repozytoriów cyfrowych w opinii uczestników II etapu III edycji Olimpiady Medialnej w 2014 r. Analiza jakościowa, w: Olimpiada Medialna, Badania nad świadomością uczestników, Warszawa 2014, s. 53-65.

Drzewiecki P., Młodzi o programie ramowym TVP1. Analiza jakościowa prac finalistów II edycji Olimpiady Medialnej w 2013 r., w: Olimpiada Medialna, Badania nad świadomością uczestników, Warszawa 2014, s. 39-52.

Fundacja Nowe Media, Regulamin IV Olimpiady Medialnej, Warszawa 2014, archiwum autora.

Guger C., Using a brain/computer interface for smart-home control, "PerAda Magazine Toward pervasive adaptation”, 2009. 
Jacobson M. M., Mappus M., Applications for Brain-Computer Interfaces, w: Brain-Computer Interfaces: Applying our Minds to Human-Computer Interaction part 2, s. 89-103.

Jakobson R., W poszukiwaniu istoty języka. Wybór pism, (red.) M. R. Mayenowa, t. 1, Warszawa 1989.

Kosinski M., D. Stillwell, T. Graepel, Private traits and attributes are predictable from digital records of human behavior, "Proceedings of the National Academy of Sciences” 2013, nr 110.15, s. 5802-5805.

McLuhan M., Zrozumieć media: przedłużenia człowieka, Warszawa 2004.

Mikołajewska E., Mikołajewski D., Interfejsy mózg-komputer jako rozwiązanie dla osób niepełnosprawnych z uszkodzeniami układu nerwowego, ,Niepełnosprawność - zagrożenia, problemy, rozwiązania” 2012, nr 3 z. 4, s. 19-36.

Mikołajewska E., Mikołajewski D., The movement of a human being in the medical exoskeleton - the anthropomorfic aspects, "Antropomotoryka" 2012, $\mathrm{nr}$ 57, s. 115-121.

Paszkiel S., Błachowicz A., Zastosowanie BCI do sterowania robotem mobilnym, „Pomiary Automatyka Robotyka” 2012, nr 16, s. 270-274.

Renard Y., F. Lotte, G. Gibert, M. Congedo, M. Maby, V. Delannoy, O. Bertrand, A. Lécuyer, OpenViBE: An Open-Source Software Platform to Design, Test, and Use Brain-Computer Interfaces in Real and Virtual Environments, "Presence" 2010 t. 19, z. 1, s. 35-53.

Shead S., Amazon wciąż automatyzuje magazyny. Ile robotów w nich pracuje?, http://businessinsider.com.pl/technologie/firmy/w-magazynach-amazona-pracuje-coraz-wiecej-robotow/h8knyw8 (dostęp: 23.10.2017 r.).

Spielberg S. (reż.), A.I.: Sztuczna Inteligencja, USA, 2001.

Tapscoott D., Cyfrowa dorosłość: Jak pokolenie sieci zmienia nasz świat, Warszawa 2010.

Wachowski L., L. Wachowski, Matrix, USA, Australia, 1999.

Wimmer R. D., Dominick J. R., Mass media. Metody badań, Kraków 2008.

Wolpaw J. R., N. Birbaumer, D. J. McFarland, G. Pfurtscheller, T. M. Vaughan, Brain-computer interfaces for communication and control, "Clinical Neurophysiology" 2002, t. 113, s. 767-791.

Wrzesień W., Czy pokoleniowość nam się nie przydarzy? Kilka uwag o współczesnej polskiej młodzieży, „Nauka” 2007, nr 3, s. 131-151.

\section{OAUTORZE:}

mgr lic. Mateusz Kot - doktorant Uniwersytetu Kardynała Stefana Wyszyńskiego, asystent w Instytucie Edukacji Medialnej i Dziennikarstwa na Wydziale Teologicznym UKSW. Zajmuje się badaniem efektów edukacji medialnej oraz sposobów jej realizacji w różnych środowiskach i grupach społecznych. Zawodowo związany z Fundacją Nowe Media, gdzie odpowiada za organizację Olimpiady Medialnej. Kontakt:m.kot@uksw.edu.pl 